\title{
Validación de eficiencia del baculovirus para el control de pérdidas ocasionadas por polilla de papa
}

\author{
Validation of Efficiency of the Baculovirus for the Loss Control Caused by Pope's Moth \\ Validação da eficiência do baculovírus para o controle da perda da traça da batata
}

\author{
Jorge Alberto Arroyo Amaya \\ jorge.arroyo@unh.edu.pe \\ https://orcid.org/0000-0003-2392-4778
}

Universidad Nacional de Huancavelica, Huancavelica-Perú

\author{
Jesus Antônio Jaime Piñas \\ jesus.jaime@unh.edu.pe \\ https://orcid.org/0000-0002-7883-7105
}

Universidad Nacional de Huancavelica, Huancavelica-Perú

Artículo recibido 2 de agosto 2021 / Arbitrado y aceptado 27 de septiembre 2021 / Publicado 13 de diciembre 2021

\section{RESUMEN}

El estudio tuvo como objetivo validar la eficiencia y efectividad del talco viral baculovirus BT, en la prevención de daños ocasionado por polillas en los tubérculos semilla de papa, efectividad para el desarrollo de brotes sanos de papa almacenada con perdida racional de peso post almacenamiento en la provincia de Acobamba. El trabajo desarrollado fue científico, referido al almacenamiento de papa semilla, evaluación del umbral de daños ocasionados por la presencia de polillas, se tuvo una población de 450 tubérculos semilla de papa variedad Yungay. El nivel de investigación fue experimental. Como resultado se obtuvo el mayor porcentaje de daño a los tubérculos semilla, deterioro del tamaño de brotes, menor peso promedio de tubérculos post almacenamiento y mayor población de larvas de polillas en brotes y tubérculos se manifestó desfavorablemente cuando los tubérculos semilla fueron almacenados tradicionalmente, siendo menor los efectos en aquellos almacenados con "Silicato de magnesio hidratado": Mg3 SiO10 $(\mathrm{OH}) 2$ y Talco BT, sobresaliendo los que fueron impregnados con Talco "silicato de magnesio hidratado" la mayor protección ante las polillas fue el color blanco intenso del producto alojado en los ojos y piel de los tubérculos semilla a diferencia del Talco BT. Para finalizar El post almacenamiento (120 días), merma en peso de la semilla tubérculo de papa de $73.33 \%$, para T3 (testigo), $47.78 \%$ de Talco BT y $47.21 \%$ para Talco "silicato de magnesio Hidratado" que económicamente ocasiona una perdida/ha., de semilla para T3 (testigo) de S/. 1199.93 soles (densidad: 22727 macollos / ha., 1363.62 kg., de semilla tubérculo /ha.

Palabra clave: Validación; Eficiencia talco viral; Baculovirus; Almacenamiento; semilla
ABSTRACT

The study aimed to validate the efficiency and effectiveness of baculovirus BT viral powder in the prevention of damage caused by moths in seed potato tubers, effectiveness for the development of healthy sprouts of stored potato with rational loss of weight after storage in the province of Acobamba. The work developed was scientific, referred to the storage of seed potato, evaluation of the threshold of damage caused by the presence of moths, had a population of 450 seed potato tubers Yungay variety. The level of investigation was experimental. As a result, the highest percentage of damage to seed tubers, deterioration of sprout size, lower average weight of tubers after storage and higher population of moth larvae in sprouts and tubers were unfavorably manifested when the seed tubers were stored traditionally, being less the effects in those stored with "hydrated magnesium silicate": Mg3 SiO10 (OH)2 and Talc BT, standing out those that were impregnated with Talc "hydrated magnesium silicate" the greatest protection against moths was the intense white color of the product lodged in the eyes and skin of the seed tubers unlike Talc BT. Finally, post storage (120 days), seed potato tuber weight loss of $73.33 \%$ for T3 (control), $47.78 \%$ for Talc BT and $47.21 \%$ for Talc "magnesium silicate hydrate" which economically causes a loss/ha. of seed for T3 (control) of S/. 1199.93 soles (density: 22727 tillers / ha., $1363.62 \mathrm{~kg}$. of seed tuber / ha.).

Key word: Validation; Viral talc efficiency; Baculovirus; Storage; seed

\section{RESUMO}

O estudo visou validar a eficiência e eficácia do pó viral baculovírus BT na prevenção de danos causados por mariposas em tubérculos de batatassemente, eficácia para o desenvolvimento de brotos saudáveis de batatas armazenadas com perda racional de peso após o armazenamento na província de Acobamba. O trabalho desenvolvido foi científico, referente ao armazenamento da batata semente, avaliação do limiar de dano causado pela presença de traças, tinha uma população de 450 tubérculos de semente de batata da variedade Yungay. O nível de pesquisa foi experimental. Como resultado, a maior porcentagem de danos aos tubérculos de sementes, a deterioração do tamanho do broto, o menor peso médio dos tubérculos após 0 armazenamento e a maior população de larvas de traça nos brotos e tubérculos se manifestou desfavoravelmente quando os tubérculos de sementes eram armazenados tradicionalmente, sendo menores os efeitos naqueles armazenados com "silicato de magnésio hidratado": Mg3 SiO10 (OH)2 e Talc BT, destacando-se aqueles que foram impregnados com Talc "silicato de magnésio hidratado" a maior proteção contra traças foi a cor branca intensa do produto alojado nos olhos e na pele dos tubérculos das sementes, ao contrário do Talc BT. Finalmente, pós armazenamento (120 dias), perda de peso do tubérculo de batata de semente de $73,33 \%$ para T3 (controle), $47,78 \%$ para Talc BT e $47,21 \%$ para Talc "silicato de magnésio hidratado", o que economicamente causa uma perda/ha. de sementes para T3 (controle) de S/. 1199,93 solas (densidade: 2272727 tubérculos/ha., $1363,62 \mathrm{~kg}$. de tubérculo de semente/ha.).

Palavra-chave: Validação; eficiência do talco viral; Baculovírus; Armazenamento; semente 


\section{INTRODUCCIÓN}

En la Región Huancavelica en Perú se encuentra un gran número de variedades de papa nativa. Algunas de ellas son de mayor importancia por su área cultivada, por su adaptación y por su preferencia en los mercados locales y extra regionales. En Huancavelica durante los años 2010-2011 se siembra entre 18,000 a 24,000 hectáreas de papa. Sin embargo, el rendimiento promedio es aún bajo ( 7 - $8 \mathrm{t} / \mathrm{ha})$ debido a varias causas por los daños es afectado por numerosos organismos de la polilla de la papa que, en determinadas condiciones, causan daño económico. (1).

En la actualidad Perú es un país productor de papa en diversas regiones de la sierra, pero la producción se ve disminuido por que las plagas son importantes factores bióticos que afectan y limitan la producción de papa en la región andina. Dependiendo de su nivel de infestación, las pérdidas en calidad y cantidad pueden llegar fácilmente hasta un $70 \%$, lo que afecta seriamente los ingresos de los agricultores y la seguridad alimentaria es afectado en su mayoría por la polilla de la papa es la principal plaga del cultivo por su amplia distribución en el ámbito regional (2). Existe un complejo de polillas entre las que figuran Phthorimaea operculella, Symmetrischema sp., y, Tecia solanivora (Guatemalteca) no obstante su distribución geográfica que se inició en Guatemala está incrementándose y amenazando algunos países de Sudamérica como Venezuela, Colombia y Ecuador donde ha sido recientemente introducida y está causando daños irreparables (3), esta última especie aun no la tenemos en las regiones altoandinas, sin embargo, no se está exento de su aparición en los campos agrícolas del sembrío de Papa. La primera especie ataca a toda la planta. Symmetrischema sp., se alimenta de tallos y tubérculos, siendo los mayores daños, en ambas especies, en almacén (4).

Dentro de los métodos de control que se han desarrollado para la polilla de la papa, se encuentra el control cultural con el buen uso y manejo de prácticas culturales, control etológico con el uso de feromonas sexuales con fines de monitorear la población y el control biológico sean estos parasitoides o entomopatógenos. Dentro de este último método de control, el uso de Báculo virus phthorimaea es el más desarrollado y utilizado por su efectividad en el control de la polilla de la papa en almacenamiento de semilla (5).

$\mathrm{El}$ virus granulosis de Phthorimaea operculella (Po VG) es un patógeno que afecta el desarrollo larval de la polilla de la papa. Las larvas enfermas son de color blanco lechoso, más lentas y se alimentan menos, no logran empupar y mueren entre los 12 y 21 días en condiciones de costa después de haber ingerido el virus. Este patógeno es multiplicado en forma masiva sobre una crianza de la polilla de la papa, para contar con el mayor número de larvas enfermas. Para la formulación del producto en polvo seco, se necesitan 20 larvas enfermas y un kilo de talco (silicato de magnesio) en un litro de agua. La dosis recomendada es de $5 \mathrm{~kg}$ por cada tonelada de 
papa a tratar, el cual protege de la infestación por cuatro meses de almacenamiento (6).

\section{MATERIALES Y MÉTODOS}

El trabajo de investigación se desarrolló en el Lugar denominado "Vista Hernmosa Casa Blanca", distrito de Acobamba, provincia de Acobamba. Región Huancavelica. Ubicado a 3423 m.s.n.m, teniendo las ubicaciones geográficas de las coordenadas de Latitud Sur $12^{\circ}$ 50' 37.32", Longitud Oeste 74' 34'41.46", el tipo de Investigación fue exploratorio que permitió la validación científica del uso del talco viral Baculovirus (7). Los baculovirus son virus patógenos de insectos ampliamente empleados a nivel mundial como bioinsecticidas para el control de diferentes plagas de importancia agrícola y más recientemente como vectores de expresión de proteínas y vectores para terapia génica. Una de sus características principales es su alta especificidad de hospedero que incluye un rango muy estrecho de especies de insectos, que a menudo pertenecen a la misma familia (8). El nivel de investigación fue el Experimental donde se desarrolló tecnologías ya generadas o exitosas en otros ámbitos a fin de reducir la incertidumbre de adaptabilidad y validación de la misma, mediante información experimental de calidad a una escala que nos permitió la verificación de los datos técnicos, empleando el Diseño de Block Completamente Randomizado (DBCR) con comparaciones múltiples Tukey $=0.05$, se trabajó con una población de 450 tubérculos de cultivo de Papa variedad Yunga, La muestra del estudio era la totalidad de tubérculos acopiados con tratamiento y sin tratamiento almacenados en condiciones naturales 09 jabas de almacenamiento ubicado en el predio "Vista Hermosa Casa Blanca" Acobamba. Huancavelica. las larvas apenas eclosionan son bastante activas haciendo su daño de acuerdo a su lugar de oviposición. Terminando su desarrollo se convierten en pupa, las que son totalmente inactivas y bastante susceptibles a cualquier daño mecánico (9). Los adultos emergen rompiendo la exuvia generalmente en las noches y muy pocas veces en el día, son ovíparos, son de actividad nocturna, y también ovipositan en la noche, en el día permanecen ocultos en el follaje.

El muestreo de cada unidad experimental se evaluaron los daños en almacén de papa/ Jaba almacenada a Luz difusa, considerando el peso del Tubérculo al inicio y termino del almacenamiento, las evaluaciones de la población de larvas de polillas se evaluaron al terminar el ciclo de almacenamiento los daños al término del período de almacenamiento en los tubérculos tratados fueron de 0 a 1,2 \%, mientras que en los tubérculos sin tratar fue de 5,2 a $39.98 \%$, daño en tubérculos y numero de brotes ulterior al brotamiento concluido a 120 días después del almacenamiento (10).

Los adultos emergen rompiendo la exuvia generalmente en las noches y muy pocas veces en el día, son ovíparos, son de actividad nocturna, y también ovipositan en la noche, en el día permanecen ocultos en el follaje (11). El muestreo de cada unidad experimental se 
evaluaron los daños en almacén de papa/ Jaba almacenada a Luz difusa, considerando el peso del Tubérculo al inicio y termino del almacenamiento, las evaluaciones de la población de larvas de polillas se evaluaron al terminar el ciclo de almacenamiento los daños al término del período de almacenamiento en los tubérculos tratados fueron de 0 a 1,2\%, mientras que en los tubérculos sin tratar fue de 5,2 a $39.98 \%$, daño en tubérculos y numero de brotes ulterior al brotamiento concluido a 120 días después del almacenamiento (12).

\section{Procedimiento o fases de campo (almacén)}

El procedimiento fue la revisión superficial del daño de las larvas ocasionado en la piel de los tubérculos con aplicación de Talco viral baculovirus $\mathrm{BT}$, tubérculos impregnados con Talco "silicato de magnesio hidratado" $\mathrm{Mg}_{3} \mathrm{SiO}_{10}(\mathrm{OH})_{2}$ : comparados con tubérculos sin ningún control, con el objetivo de validar la prevención de daños ocasionados por las polillas en los tubérculos semilla de papa almacenada (13).

\section{Peso del tubérculo}

El peso en tubérculos se determinó con aplicación de Talco viral baculovirus BT, tubérculos impregnados con Talco "silicato de magnesio hidratado" $\mathrm{Mg}_{3} \mathrm{SiO}_{10}(\mathrm{OH})_{2}$ : comparados con tubérculos sin ningún control, el objetivo es validar la eficiencia y efectividad del Talco viral baculovirus BT, para disminuir la pérdida de peso de los tubérculos semilla de papa almacenados.

\section{Población de larvas de polillas}

La mortalidad de larvas de polillas en tubérculos y jabas de almacenamiento con aplicación de Talco viral baculovirus BT, tubérculos impregnados con Talco "silicato de magnesio hidratado" $\mathrm{Mg}_{3} \mathrm{SiO}_{10}(\mathrm{OH})_{2}$ : comparado con tubérculos sin ningún control, nos permitió validar la eficiencia del Talco viral baculovirus BT en la protección de tubérculos semilla ante la presencia de larvas de polillas en los tubérculos semilla de papa en almacén en la Provincia de Acobamba.

\section{Cantidad de tubérculo semilla dañado}

El conteo de tubérculo semilla dañados con aplicación de Talco viral baculovirus BT, tubérculos impregnados con Talco "silicato de magnesio hidratado" $\mathrm{Mg}_{3} \mathrm{SiO}_{10}(\mathrm{OH})_{2}$ : comparados con tubérculos sin ningún control, nos permitió certificar la efectividad del Talco viral baculovirus BT en la protección de tubérculos semilla al daño de larvas de polillas en los tubérculos semilla de papa en almacén en la Provincia de Acobamba.

\section{Número de brotes por tubérculos después de $\mathbf{1 2 0}$ días}

El número de brotes sanos de tubérculo semilla con aplicación de Talco viral baculovirus BT, tubérculos impregnados con Talco "silicato de magnesio hidratado" $\mathrm{Mg}_{3} \mathrm{SiO}_{10}(\mathrm{OH})_{2}$ : comparados con tubérculos sin ningún control, permitió refrendar la certeza del Talco viral baculovirus BT para el desarrollo de brotes sanos en condiciones de almacén en la Provincia de Acobamba. 


\section{RESULTADOS Y DISCUSIÓN}

\section{Análisis de información}

Promedio de los niveles de tratamientos empleando el talco viral para el controlar el porcentaje de daños en tubérculos de papa semilla, (Tabla 1).

Tabla 1. Promedio \% de daño en tubérculos ( $\mathrm{N} \%$ tratamiento).

\begin{tabular}{lcccc}
\hline \multirow{2}{*}{ REPETICIONES } & \multicolumn{3}{c}{ NIVELES DE TRATAMIENTO } & SX.j \\
\hline REP 1 & T1 (Talco viral) & T2 (Talco) & T3 (Testigo) & 38.7 \\
REP 2 & 2.5 & 1.2 & 35 & 39 \\
REP 3 & 2.5 & 1.5 & 35 & 44.7 \\
SXi. & 3.2 & 1.5 & 40 & 122.4 \\
\hline PROMEDIO & 8.2 & 4.2 & 110 & $\mathbf{1 3 . 6}$ \\
\hline
\end{tabular}

Como se indica en la Tabla 1, el tratamiento de los porcentajes de daño fue el mayor para el $\mathrm{T} 3=36.67$, donde se encontró mayor cantidad de ataque de la Larvas de la Polilla de la papa, seguido del uso del talco viral con el porcentaje de 2.73 , teniendo el menor daño de los tubérculos el T2=1.4 de porcentaje resultado del uso de talco para se controló el ataque del daño de la polilla.

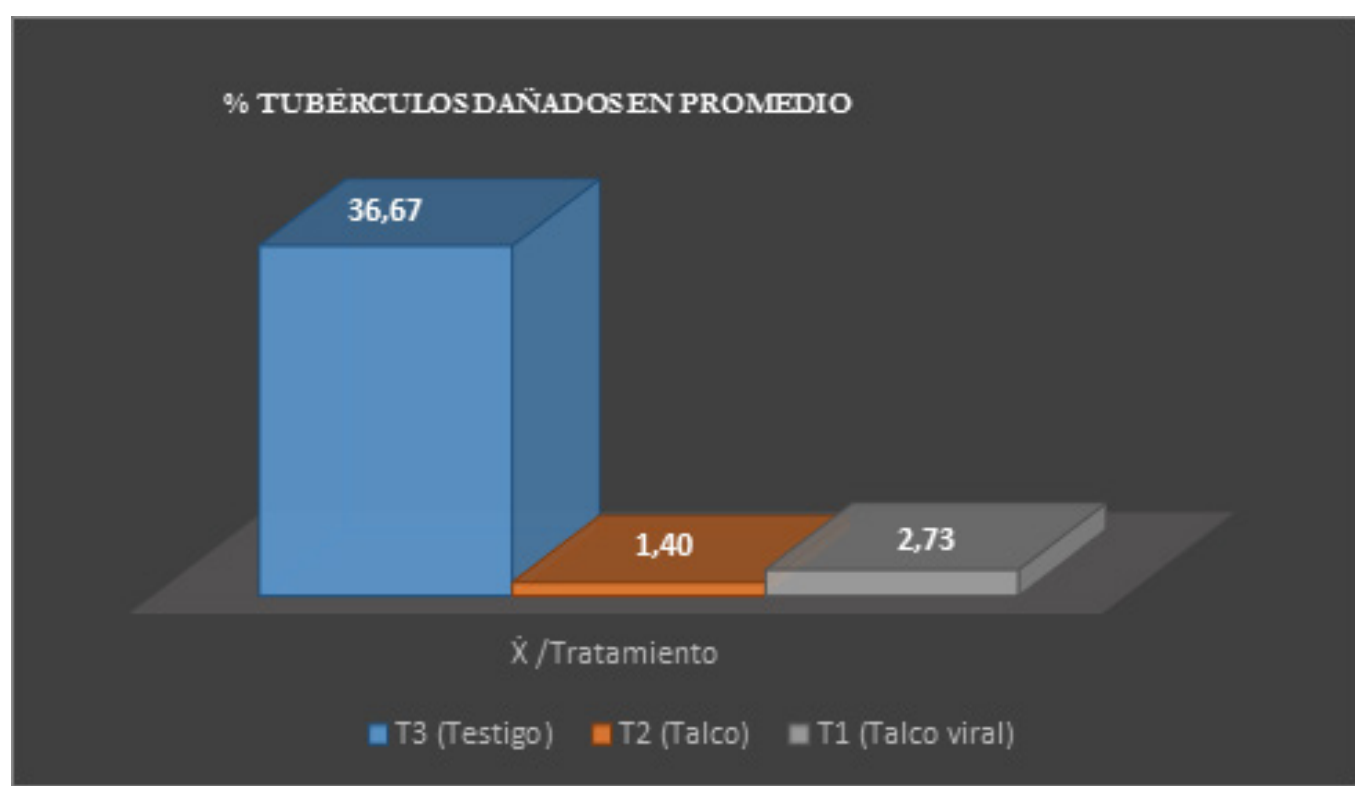

Figura 1. Representación Gráfica del número de tubérculos dañados en Promedio /tratamiento. 
En la Figura 1 se demuestra de manera indubitable que los tubérculos almacenados de la manera tradicional "testigo" expreso un alto \% de daño en tubérculos alcanzando $36.67 \%$ de tubérculos dañados, siendo de tan solo $1.4 \%$ en aquellos tubérculos semilla almacenados con talco "silicato de magnesio hidratado": $\mathrm{Mg}_{3} \mathrm{SiO}_{10}(\mathrm{OH})_{2}$

\section{Análisis de varianza para \% de daños en tubérculos de los tratamientos}

Resultado de los análisis de varianza al 0.05 y 0.01 de los tratamientos, (Tabla 2).

Tabla 2. Análisis de Varianza para \% de daños en tubérculos de los tratamientos.

\begin{tabular}{|c|c|c|c|c|c|c|c|}
\hline \multirow{2}{*}{$F$ de V } & \multirow{2}{*}{ G.L. } & \multirow{2}{*}{ S.C. } & \multirow{2}{*}{ C.M. } & \multirow{2}{*}{ Fc. } & \multicolumn{2}{|c|}{ Ft. } & \multirow{2}{*}{ Sig. } \\
\hline & & & & & 0.05 & 0.01 & \\
\hline Repeticiones & 2 & 7.62 & 3.81 & 1.62 & 6.94 & 18 & N.S \\
\hline Tratamiento & 2 & 2396.99 & 1198.49 & 508.2 & 6.94 & 18 & $* \star$ \\
\hline Error & 4 & 9.43 & 2.36 & & & & \\
\hline Total & Sni-1=8 & 2414.04 & & & & & \\
\hline
\end{tabular}

En la Tabla 2 se muestra el análisis de varianza de los tratamientos, el \% de daños para tratamientos exhibe diferencia estadística altamente significativa entre tratamientos lo que asegura almacenar la semilla tubérculo de papa con material inerte de color blanco puede asegurar un efecto positivo frente al daño de las polillas de papa, toda vez que el daño fue menor en los tubérculos que fueron almacenados con talco "silicato de magnesio hidratado" $\mathrm{Mg}_{3} \mathrm{SiO}_{10}(\mathrm{OH})_{2}$ y Talco BT., siendo el primero utilizando solo silicato de magnesio hidratado que presento un $1.4 \%$ de daños, lo cual reporta mínimas perdidas de tubérculos semilla de papa.

\section{Promedio de brotes dañados post almacenamiento de tubérculos}

En la Tabla 3 está referida al promedio de brotes dañados de papa semilla almacenados que indican que para $\mathrm{T} 3=146$, seguido el $\mathrm{T} 1=27.67$, ubicando se en último lugar el T2=17.67, respuesta que se presentó en relación al porcentaje de daños en tubérculos por ataque de las polillas, el promedio \% de brotes daños manifestó ser mayor en aquellos tubérculos semilla que fueron almacenados de la forma tradicional, se aprecia semillas que fueron almacenados con talco "silicato de magnesio hidratado" $\mathrm{Mg}_{3} \mathrm{SiO}_{10}(\mathrm{OH})_{2}$, manifiesta menor promedio de daño de brotes que los tubérculos que fueron almacenados con Talco BT. 
Tabla 3. Promedio de brotes dañados post almacenamiento ( $\mathrm{N}^{\circ} /$ tratamiento).

\begin{tabular}{lcccc}
\hline \multicolumn{1}{c}{ REPETICIONES } & \multicolumn{3}{c}{ NIVELES DE TRATAMIENTO } & SX.j \\
\hline REP 1 & T1 (Talco viral) & T2 (Talco) & T3 (Testigo) & 190 \\
REP 2 & 25 & 20 & 145 & 183 \\
REP 3 & 20 & 18 & 145 & 201 \\
SXi. & 38 & 15 & 148 & 574 \\
\hline PROMEDIO & 83 & 53 & 438 & $\mathbf{6 3 . 7 8}$ \\
\hline
\end{tabular}

En la Figura 2 se muestra el número de brotes dañados post almacenamiento indicando que los tubérculos almacenados de la manera tradicional "Testigo" T3, Indica un alto número de daño de brotes en los tubérculos alcanzando 146; seguido de brotes dañados el T2, con tan solo 17.67 , promedio en aquellos tubérculos semilla almacenados con talco "silicato de magnesio hidratado" $\mathrm{Mg}_{3} \mathrm{SiO}_{10}(\mathrm{OH})_{2}$, y el T1, de 27.67 promedio de brotes dañados de los tubérculos que fueron almacenados con Talco BT.

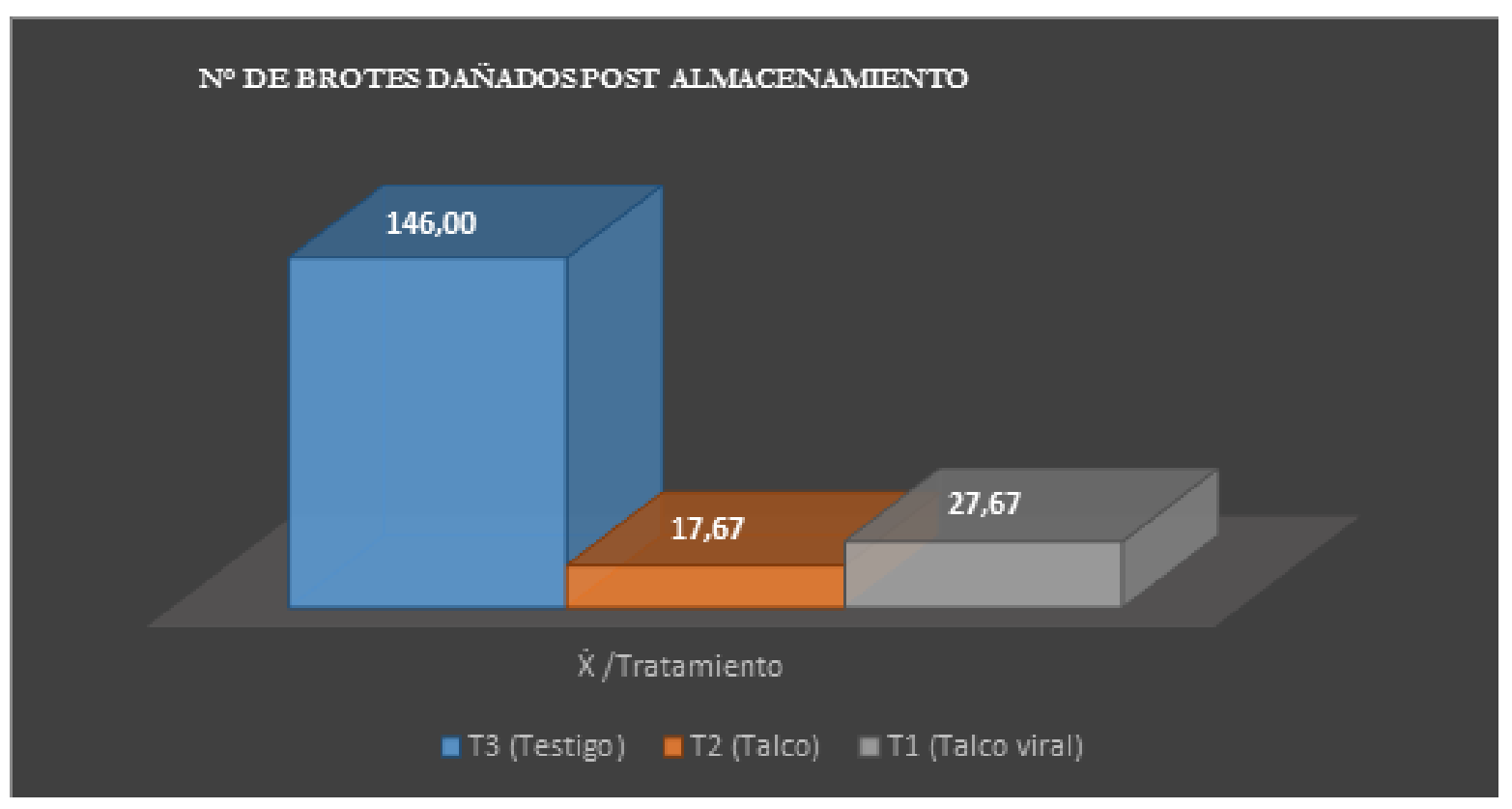

Figura 2. Representación Gráfica de Promedio de brotes dañados post almacenamiento / tratamiento.

\section{Promedio poblacional de larvas en tubérculos dañados post almacenamiento}

Promedio de los tratamientos de los niveles de uso talco para el promedio de larvas hallada en los tubérculos dañados, (Tabla 4). 
Tabla 4. Promedio poblacional de larvas en tubérculos dañados ( $\mathrm{N}^{\circ} /$ tratamiento).

\begin{tabular}{lcccc}
\hline \multirow{2}{*}{ REPETICIONES } & \multicolumn{3}{c}{ NIVELES DE TRATAMIENTO } & SX.j \\
\hline REP 1 & T1 (Talco viral) & T2 (Talco) & T3 (Testigo) & 74 \\
REP 2 & 8 & 4 & 62 & 70 \\
REP 3 & 7 & 5 & 58 & 76 \\
SXi. & 7 & 4 & 65 & 220 \\
\hline PROMEDIO & 22 & 13 & 185 & $\mathbf{2 4 . 4 4 4}$ \\
\hline
\end{tabular}

En la Tabla 4 el promedio poblacional de larvas en tubérculos dañados ( $\mathrm{N}^{\circ} /$ tratamiento) se puede considerar que en el tratamiento $\mathrm{T}_{3}$ (testigo) sin cubierta se presentó un 61.67 en promedio de larvas de polillas, siendo menor en las que fueron almacenados con cobertura a base de talco "silicato de magnesio hidratado" $\mathrm{Mg}_{3} \mathrm{SiO}_{10}(\mathrm{OH})_{2}$ y Talco BT., sobresaliendo las que fueron recubiertas con talco con 4.33 en promedio de larvas halladas en los tubérculos dañados.
En la Figura 3 el promedio poblacional de larvas halladas en los tubérculos dañados por las polillas observados lo que se manifestaron en una menor presencia de larvas fueron las que tuvieron cubierta de talco" silicato de magnesio hidratado" $\mathrm{Mg}_{3} \mathrm{SiO}_{10}(\mathrm{OH})_{2}$ y Talco $\mathrm{BT}$, sobre saliendo las que fueron recubiertas con talco el T2 con 4.33 de población larval

\section{PROMEDIO POBLACIONAL DE LARVASEN TUBERCULOS DAÑADOS}

\section{1,67}

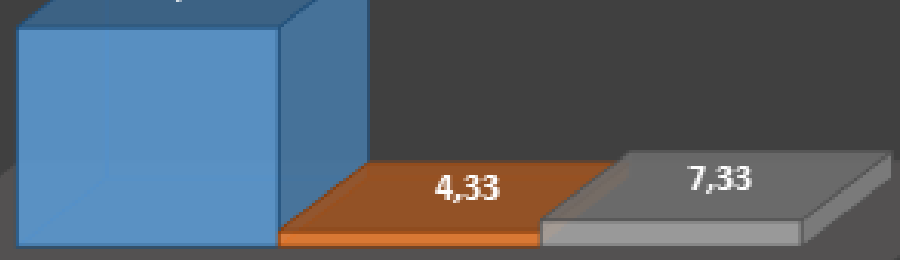

\section{$\dot{\mathrm{X}} /$ Tratamiento}

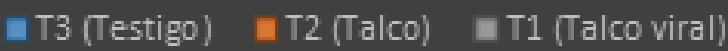

Figura 3. Representación Gráfica de Promedio poblacional de larvas en Tubérculos dañados ( $\mathrm{N}$ /tratamiento). 


\section{Análisis de varianza de promedio poblacional de larvas en tubérculos dañados}

Resultados de promedios de los análisis de varianza al 0.05 y $0.01 \%$ de la población de larvas en tubérculos dañados, (Tabla 5).

Tabla 5. Análisis de Varianza de promedio poblacional de larvas en tubérculos dañados de los Tratamientos.

\begin{tabular}{|c|c|c|c|c|c|c|c|}
\hline \multirow{2}{*}{ F de V } & \multirow[b]{2}{*}{ G.L. } & \multirow[b]{2}{*}{ S.C. } & \multirow[b]{2}{*}{ C.M. } & \multirow[b]{2}{*}{ Fc. } & \multicolumn{2}{|c|}{ Ft. } & \multirow[b]{2}{*}{ Sig. } \\
\hline & & & & & 0.05 & 0.01 & \\
\hline Repeticiones & 2 & 6.22 & 3.11 & 0.63 & 6.94 & 18 & N.S \\
\hline Tratamiento & 2 & 6248.22 & 3124.11 & 631.84 & 6.94 & 18 & ** \\
\hline Error & 4 & 19.78 & 4.94 & & & & \\
\hline Total & Sni-1=8 & 6274.22 & & & & & \\
\hline
\end{tabular}

$\mathrm{CV}=9.10$

En la Tabla 5 el análisis e varianza de los tratamientos para el promedio poblacional de larvas en tubérculos dañados, ( $\mathrm{N} \%$ tratamientos) se detalla que existe diferencia estadística altamente significativo entre los tratamientos esto debido a la forma como fueron almacenados los tubérculos semilla de papa T3 (testigo) Sion cubierta y con cobertura a base de talco "silicato de maganesio hidratado" $\mathrm{Mg}_{3} \mathrm{SiO}_{10}(\mathrm{OH})_{2}$ y Talco BT., sobresaliendo las que fueron recubiertas con talco con 4.33 en promedio de larvas halladas en los tubérculos dañados.

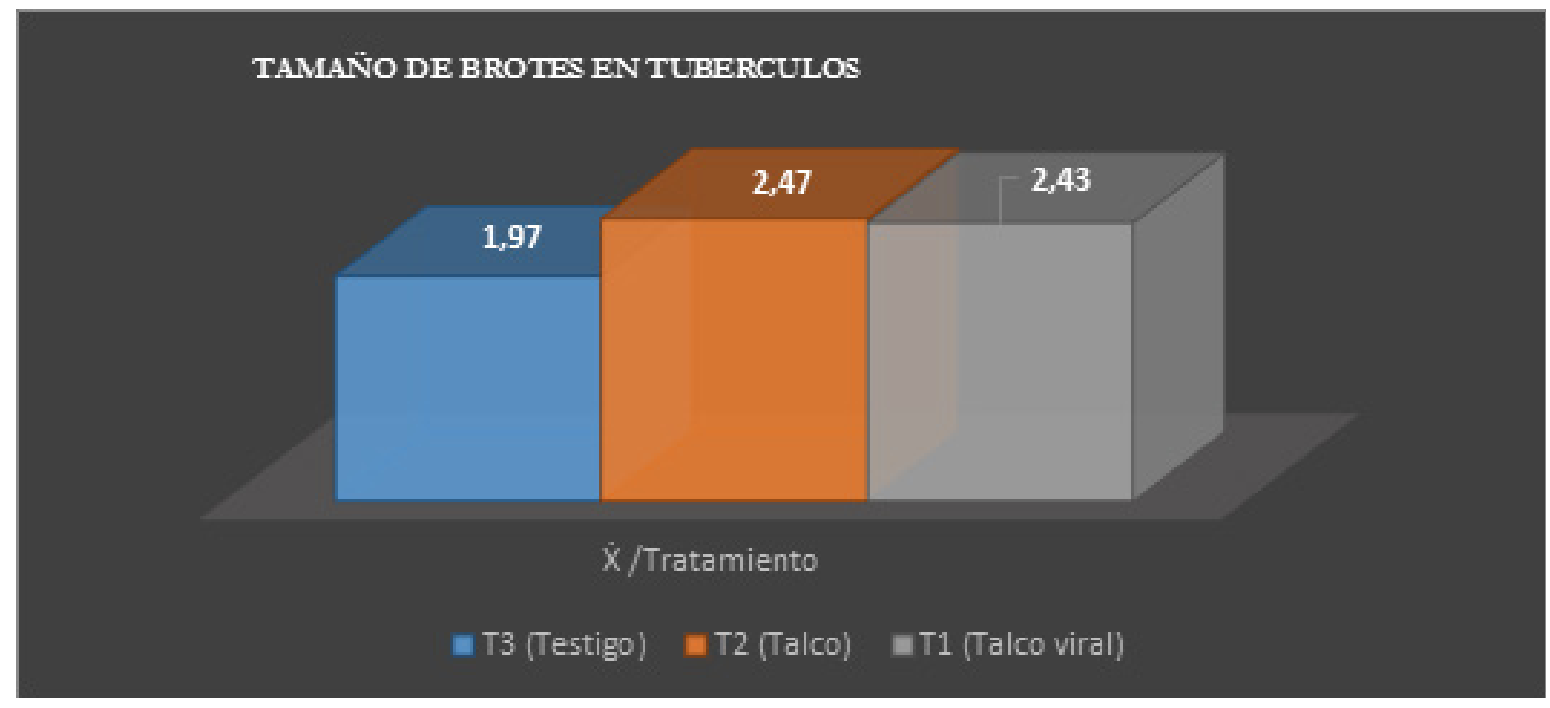

Figura 4. Representación Gráfica de Tamaño de brotes en tubérculos (cm.) (Tamaño /tratamiento). 
En la Figura 4 relacionada con la y los tubérculos semilla de papa $\mathrm{T}_{3}$ (testigo) representación gráfica de Tamaño de brotes en tubérculos (cm.) (tamaño / tratamiento) se aprecia que los que manifestaron un mayor tamaño de brotes fueron los que tuvieron cubierta de talco "silicato de magnesio hidratado" $\mathrm{Mg}_{3} \mathrm{SiO}_{10}(\mathrm{OH})_{2}$ y Talco BT., sobresaliendo los que fueron recubiertos con talco con $2.47 \mathrm{~cm}$., de longitud de brote almacenados sin cubierta lograron $1.97 \mathrm{~cm}$., de tamaño de brotes.

\section{Análisis de varianza para tamaño de brotes de los tratamientos}

Resultado de la del análisis de varianza de los tratamientos del tamaño de los brotes al 0.05 y 0.01 , (Tabla 6$)$.

Tabla 6. Análisis de Varianza para tamaño de brotes de los Tratamientos.

\begin{tabular}{|c|c|c|c|c|c|c|c|}
\hline \multirow{2}{*}{$F$ de V } & \multirow{2}{*}{ G.L. } & \multirow{2}{*}{ S.C. } & \multirow{2}{*}{ C.M. } & \multirow{2}{*}{ Fc. } & \multicolumn{2}{|c|}{ Ft. } & \multirow{2}{*}{ Sig. } \\
\hline & & & & & 0.05 & 0.01 & \\
\hline Repeticiones & 2 & 0.04 & 0.02 & 16 & 6.94 & 18 & N.S \\
\hline Tratamiento & 2 & 0.47 & 0.23 & 211 & 6.94 & 18 & $\star \star$ \\
\hline Error & 4 & 0 & 0 & & & & \\
\hline Total & Sni- $1=8$ & 0.51 & & & & & \\
\hline
\end{tabular}

$\mathrm{CV}=1.46$

En La Tabla 6. el análisis de Varianza para tamaño de brotes de los tratamientos, nos refiere que existe diferencia estadística altamente significativa entre los tratamientos esto debido a la forma como fueron almacenados los tubérculos semilla de papa $\mathrm{T}_{3}$ (testigo) sin cubierta y con cobertura a base de talco "silicato de magnesio hidratado"
$\mathrm{Mg}_{3} \mathrm{SiO}_{10}(\mathrm{OH})_{2}$ y Talco BT., sobresaliendo las que fueron recubiertas con talco.

Promedio peso de tubérculos post almacenamiento

Resultados de los promedios de los niveles de tratamientos del peso de tubérculos post almacenamiento, (Tabla 7). 
Tabla 7. Promedio peso de tubérculos post almacenamiento (g.) (Peso/tratamiento).

\begin{tabular}{lcccc}
\hline \multirow{2}{*}{ REPETICIONES } & \multicolumn{3}{c}{ NIVELES DE TRATAMIENTO } & SX.j \\
\hline REP 1 & T1 (Talco viral) & T2 (Talco) & T3 (Testigo) & 83 \\
REP 2 & 32 & 33 & 18 & 75 \\
REP 3 & 30 & 30 & 15 & 79 \\
SXi. & 32 & 32 & 15 & 237 \\
\hline PROMEDIO & 94 & 95 & 48 & $\mathbf{2 6 . 3 3 3}$ \\
\hline
\end{tabular}

Como se puede apreciar en la Tabla 7, el peso promedio de tubérculos post almacenamiento (g.) (Peso/tratamiento), existe una diferencia en todos los tratamientos siendo esta diferencia menor en los tubérculos con cobertura a base de talco "silicato de magnesio hidratado" $\mathrm{Mg}_{3} \mathrm{SiO}_{10}(\mathrm{OH})_{2}$ y Talco BT., sobresaliendo las que fueron recubiertas con talco con 31.67 g., alcanzando una mayor diferencia el tratamiento $\mathrm{T}_{3}$ (testigo) sin cubierta con $16 \mathrm{~g}$.

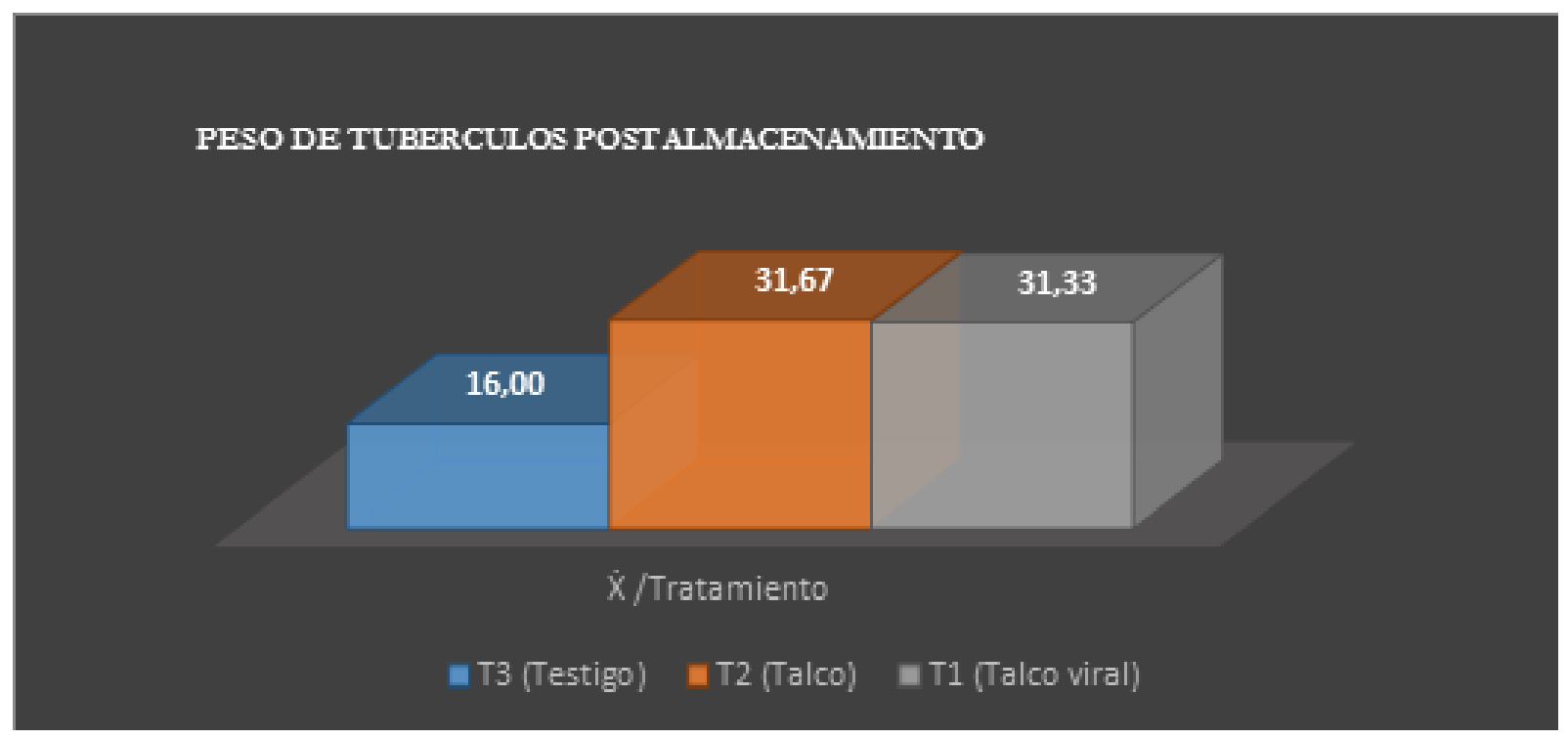

Figura 5. Representación Gráfica de Peso de tubérculos post almacenamiento (g.) (Peso/tratamiento).

En la Figura 5 de peso de tubérculos post almacenamiento (g.) (Peso/ tratamiento, se observa que existe diferencia en relación al peso de tubérculos post almacenamiento existe una diferencia en todos los tratamientos siendo esta diferencia menor en los tubérculos con cobertura a base de talco "silicato de magnesio hidratado" $\mathrm{Mg}_{3} \mathrm{SiO}_{10}(\mathrm{OH})_{2}$ y Talco BT., sobresaliendo las que fueron recubiertas con talco con 31.67 g., alcanzando una mayor diferencia el tratamiento $\mathrm{T}_{3}$ (testigo) sin cubierta con un peso menor $16 \mathrm{~g}$. 


\section{Análisis de varianza de peso de tubérculos post almacenamiento}

Resultado del análisis de varianza al 0.05 y $0.01 \%$ del peso de los tubérculos post almacenamiento de semilla papa, (Tabla 8).

Tabla 8. Análisis de varianza de peso de tubérculos post almacenamiento de los Tratamientos.

\begin{tabular}{lllllllll}
\hline \multicolumn{1}{c}{ F de V } & & G.L. & S.C. & C.M. & Fc. & 0.05 & . 01 & Sig. \\
\hline Repeticiones & 2 & 10.67 & 5.33 & 8 & 6.94 & 18 & N.S \\
Tratamiento & 2 & 480.67 & 240.33 & 360.5 & 6.94 & 18 & $*$ \\
Error & 4 & 2.67 & 0.67 & & & & \\
\hline Total & Sni-1=8 & $\mathbf{4 9 4}$ & & & & & \\
\hline
\end{tabular}

En la Tabla 8. Análisis de Varianza de peso de tubérculos post almacenamiento de los Tratamientos, refiere que existe diferencia estadística altamente significativa entre los tratamientos esto debido a la forma como fueron almacenados los tubérculos semilla de papa $T_{3}$ (testigo) sin cubierta y con cobertura a base de talco "silicato de magnesio hidratado" $\mathrm{Mg}_{3} \mathrm{SiO}_{10}(\mathrm{OH})_{2}$ y Talco BT., sobresaliendo las que fueron recubiertas con talco.

\section{Discusión}

Los daños en tubérculos por presencia de larvas de las polillas de la papa se vieron incrementados según el proceso de almacenamiento de los tubérculos semilla de papa, pudiéndose inferir de acuerdo a los resultados obtenidos que el mayor porcentaje de daño ocurrió en aquellos tubérculos semilla que fueron almacenados de forma tradicional sin ningún tipo de cobertura o empapado (14) describe en su Tesis, Control biológico e interacción de baculovirus PoGV, y Bacillus thuringiensis var Kurstaki sobre polilla de la papa (15), uno de los cultivos ancestrales y de gran riqueza genética en nuestro país es la papa Solanum tuberosum L., En el trabajo de investigación los menos afectados los que fueron almacenados con "silicato de magnesio hidratado" $\mathrm{Mg}_{3} \mathrm{SiO}_{10}(\mathrm{OH})_{2}$ y Talco BT pues manifestaron menor \% de daño, sobresaliendo los que fueron impregnados con "silicato de magnesio hidratado" que brindo una mayor protección a los tubérculos al daño de las polillas posiblemente debido al color blanco intenso del producto aun tratándose de solo materia inerte a diferencia del Talco BT.

La pérdida de brotes dañados de papa semilla almacenados fue mayor en aquellos tubérculos semilla que fueron almacenados de forma tradicional sin ningún tipo de cobertura o impregnado, siendo los menos afectados los que fueron almacenados cubiertos con "silicato de magnesio hidratado": $\mathrm{Mg}_{3} \mathrm{SiO}_{10}$ $(\mathrm{OH})_{2}$ y Talco BT pues manifestaron menor daño en sus brotes por acción de las polillas, 
sobresaliendo los que fueron impregnados con "silicato de magnesio hidratado" que brindo una mayor protección a los brotes de los tubérculos por ataque de larvas de las polillas de la papa posiblemente debido al color blanco intenso del producto alojado en los ojos de los tubérculos semilla aun tratándose de solo materia inerte a diferencia del Talco BT. La poblacional larval de polillas en tubérculos y yemas se incrementó considerablemente en el tratamiento $\mathrm{T}_{3}$ [testigo] sin cubierta alguna, a su vez manifestó menos población de larvas cuando la semilla tubérculo de papa fueron almacenados protegidos con "silicato de magnesio hidratado": $\mathrm{Mg}_{3} \mathrm{SiO}_{10}(\mathrm{OH})_{2}$ y Talco BT pues manifestaron menor población de larvas en brotes y tubérculos, sobresaliendo los que fueron impregnados con "silicato de magnesio hidratado" que brindo una mayor protección posiblemente debido al color blanco intenso del producto alojado en los ojos y piel de los tubérculos semilla aun tratándose de solo materia inerte a diferencia del Talco BT.

Con respecto al tamaño de los brotes esto también de manera similar fue afectado por los daños del estadio larval de las polillas de la papa exteriorizando: con cobertura a base de talco "silicato de magnesio hidratado": $\mathrm{Mg}_{3}$ Si $\mathrm{O}_{10}(\mathrm{OH})_{2}$, un tamaño de brote promedio de $2.47 \mathrm{~cm}$., con cubierta de Talco BT $2.43 \mathrm{~cm}$. mediante el proyecto de investigación (15) reporta en cuanto a la "Validación del uso de Baculovirus para el control de las dos polillas phthorimaea operculella y tecia solanivora en papa almacenada Y. los daños al término del período de almacenamiento en los tubérculos tratados fueron de 0 a $1,2 \%$, mientras que en los tubérculos sin tratar fue de 5,2 a $39.98 \%$, siendo de menor tamaños los que se desarrollaron en los tubérculos semilla de papa $\mathrm{T}_{3}$ (testigo) sin cubierta $1.97 \mathrm{~cm}$.

Conrelaciónalpeso promedio de tubérculos post almacenamiento (g.), existe una diferencia marcada en todos los tratamientos siendo esta menor en los tubérculos con cobertura a base de talco "Silicato de magnesio hidratado": $\mathrm{Mg}_{3} \mathrm{Si}_{10}(\mathrm{OH})_{2}$ y Talco BT sobresaliendo las que fueron recubiertas con talco con 31.67 g., alcanzando una mayor diferencia el tratamiento $\mathrm{T}_{3}$ (testigo) sin cubierta con $16 \mathrm{~g}$., se deduce finalmente que post almacenamiento (120 días), se produce una merma en peso de la semilla tubérculo de papa para el caso $\mathrm{T}_{3}$ testigo del $73.33 \%$, Talco BT $47.78 \%$ y para Talco "silicato de magnesio Hidratado" de $47.21 \%$ lo cual económicamente representa una perdida por hectárea de semilla para el caso testigo de S/. 1199.93 soles (densidad: 22727 macollos / ha., 1363.62 kg., de semilla tubérculo /ha., costo de semilla / ha., 1636.34 soles).

\section{CONCLUSIONES}

Los resultados obtenidos en el estudio de investigación permitieron llegar a las siguientes conclusiones:

El uso de brotes de eficiencia y efectividad del talco viral baculovirus BT, en la prevención de daños ocasionado por polillas en los tubérculos semilla de papa, tuvo resultados favorables para el control de la polilla de papa; se logró controlar con el uso del Talco "silicato 
de magnesio hidratado" permitiendo la mayor protección a los brotes de los tubérculos por ataque de larvas de polillas de la papa, esto fue debido al color blanco intenso del producto impregnado en la piel y alojado en los ojos de los tubérculos semilla.

Se evaluó las semillas almacenadas donde se identificó a la especie Symmetrischema sp. mas no Phthorimaea operculella siendo de incidencia y severidad alta en las semillas de papas sin cubierta que presentó 61.67 larvas, los valores bajos con el uso de Talco "silicato de magnesio Hidratado" fue de 4.33 larvas.

Durante la campaña de almacenamiento la infestación de la polilla se logró obtener los resultados de los daños en menores proporciones con la dosis aplicable $(52.5 \mathrm{~g} /$ kg de papa) una merma normal de $47.21 \%$ en peso de semilla. Con la eficiencia del Talco viral Baculovirus B. se logró una moderada respuesta para controlar al Symmetrischema sp., la mayor susceptibilidad al ataque de la polilla Symmetrischema sp. con mermas de la semilla papa al $47.78 \%$ y $73.33 \%$ fue el peso de semilla del tubérculo de papa.

En el aspecto económico en canto al post almacenamiento (120 días), la merma en peso de la semilla tubérculo de papa, fue con el uso de Talco "silicato de magnesio Hidratado" que económicamente ocasiona una perdida/ ha., de semilla en S/. 1199.93 soles (densidad: 22727 macollos / ha., 1363.62 kg., de semilla tubérculo /ha.

\section{REFERENCIAS BIBLIOGRÁFICAS}

1. Alcazar J; Cervantes M; Raman K. Caracterización y patogenicidad de un virus granulosis de la polilla de la papa Phthorímaea operculella. Rev. Per. Ent;1992;35;(3); 107-111

2. Amonkar SV; Pal AK; Vijayalakshmi L, Rao AS. Microbial control of patato tuber moth (Phthorimaea operculella Zeller), Indian Journal of experimental Biology. 1979;17(4): 1127-1133

3. Braun A, Ticle G, Fernández M. Escuelas de Campo para MIP, Manejo Integrado de Plagas. Costa Rica; 2002; 53

4. Cisneros F. Control de plagas agrícolas. Segunda edición. P. Cisneros, editor. Lima, Perú;1995

5. Keller S. Integrated pest management of the Potato tuber moth in cropping systems of different agro-ecological zones. Tropical Agriculture Vol. 11, Subseries: Advances in crop research. Editado por J. Kroschel. University of Hohenheim, Germany;2003

6. López Quispe EH, Tesis “Efectividad del virus granulosis frente al Ataque de phthorimaea operculella (zeller) en tubérculos de papa bajo condiciones de almacenamiento en el valle del Mantaro" Universidad Nacional Agraria de la Selva;1994

7. Palacios $M$, y Cisneros F. Integrated pest management for the Potato tuber moth in pilot units in the Andean Region and the Dominican Republic. En: International Potato Center Program Report; 1997

8. Proyecto Colaborativo CIP - ACDAIS Perú, Convenio Colaborativo. Proyecto Promoción del Báculo virus para el control de las polillas de la papa en almacenamiento. Sistema de Irrigación Chupaca Perú; 2003;(2):16 pp

9. Gómez Valderrama J, y Villamizar L. Baculovirus: Hostsandspecificity”, "Baculovirus. Hospederos y especificidad; 2013;(3) 
10. Mamani Sairitupac D. UNMSM - Facultad de Farmacia y Bioquímica, Tesis, Control biológico e interacción de baculovirus PoGV, y Bacillus thuringiensis var Kurstaki sobre polilla de la papa; 2008

11. Municipalidad Provincial de Acobamba. Plan Estratégico de Desarrollo Provincial Concertado y Participativo de Acobamba Perú; 2003-150

12. Municipalidad Provincial de Acobamba. Plan Estratégico de Desarrollo Provincial Concertado y Participativo de Acobamba Huancavelica. Acobamba Perú;2016;115

13. Seller S. Integrated pest management of the Potato tuber moth in cropping systems of different agro-ecological zones. Tropical Agriculture Vol 11, Subseries: Advances in crop research Editado por J. Kroschel. University of Hohenheim, Germany; 2003

14.TenorioJ.Biología,comportamientoycontrol de las polillas de la papa Symmetrischema tangolias (Gyen) y Phthorimaea operculella (Zeller) (lep: Gelechiidae) en Cajamarca. Tesis para optar el título de Ing., Agrónomo, Universidad Agraria la Molina; 1996;134

15. Jaime, JA. Et al. Promoción del Báculo virus para el control de las polillas de la papa en almacenamiento." Acobamba Perú;2007;2 